\title{
Diversitas Echinodermata di Pantai Meras Kecamatan Bunaken Sulawesi Utara (Diversity of Echinoderms on the Meras Beach, Bunaken District, North Sulawesi)
}

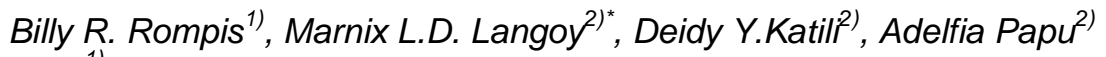 \\ 1) Alumni Jurusan Biologi, FMIPA, Universitas Sam Ratulangi \\ 2) Jurusan Biologi, FMIPA, Universitas Sam Ratulangi, Jl.Kampus Bahu, Manado 95115 \\ *Email korespondensi:marnix_langoy@yahoo.com
}

Diterima 7 Januari 2013, diterima untuk dipublikasikan 7 Februari 2013

\begin{abstract}
Abstrak
Echinodermata berperan penting pada ekosistem terumbu karang sebagai bagian dari jejaring makanan. Mereka dapat bersifat herbivora, karnivora, dan/atau omnivora. Kerusakan terumbu karang di Pantai Meras akhir-akhir ini dapat mengancam Echinodermata. Informasi tentang diversitas Echinodermata di Pantai Meras masih sedikit. Oleh karena itu, penelitian tentang diversitas Echinodermata perlu dilakukan di Pantai Meras, Kecamatan Bunaken, Sulawesi Utara. Pengambilan sampel pada tiap lokasi dilakukan pada saat surut terendah dengan menarik 3 garis transek (masing-masing 100 meter) secara vertikal dari garis pantai ke arah laut. Petak kuadrat (1 1 1 meter) diletakkan dengan jarak antar kuadrat yaitu 10 meter. Hasil penelitian menunjukkan bahwa Echinodermata hidup pada habitat padang lamun, pasir dan terumbu karang baik yang hidup maupun mati. Total species yang ditemukan yaitu 8 spesies yang termasuk anggota dari 3 kelas. Kelas Asteroidea (bintang laut) sebanyak 3 spesies, Echinoidea sebanyak 4 spesies dan Kelas Holothuroidea sebanyak 1 spesies. Diversitas Echinodermata di Pantai Meras adalah antara rendah hingga sedang dengan nilai indeks diversitas Shannon-Wiener ( $\left.H^{\prime}\right)$ berkisar antara 0,48-1,31.

Kata kunci: Diversitas Echinodermata, Pantai Meras, Sulawesi Utara
\end{abstract}

\begin{abstract}
Echinoderms have important role in coral reef ecosystems as part of the food webs. They may be herbivores, carnivores, and/or omnivores. Coral reefs destruction in Meras Beach lately can threaten Echinoderms. There was little information about Echinoderms diversity of Meras Beach. Therefore, research on Echinoderms diversity needs to be done on the Meras Beach, Bunaken District, North Sulawesi. Sampling was carried out at each location at the lowest tide. There were 3 line transects (each 100 meters) located vertically from the shoreline towards the sea. The square plots $(1 \times 1$ meter) placed distance between plots was 10 meters. The results showed that Echinoderms occupied different habitat i.e. sea grass, sand, live and/or coral reefs. Total species found 8 species belong to members of the 3 classes. Asteroidea Class (starfish), Echinoidea Class and Holothuroidea were respectively 3 species, 4 species and 1 species. Echinoderms diversity on the Meras Beach were low to moderate with Shannon-Wiener diversity index $\left(H^{\prime}\right)$ was 0.48 to 1.31 .

Keywords: Echinodermata diversity, Meras Beach, North Sulawesi
\end{abstract}




\section{PENDAHULUAN}

Echinodermata adalah hewan invertebrata yang biasanya hidup dari pantai hingga kedalaman sekitar 366 m. Hewan ini memiliki ciri yaitu hidup bebas, soliter, gerakan lamban dan tidak ada yang bersifat parasit. Predator hanya sedikit di antaranya yaitu ikan dan manusia (BTNB 2010). Secara umum, Echinodermata mencapai diversitas tertinggi di terumbu karang dan pantai dangkal. Larva dari Echinodermata, terutama bintang laut dan bulu babi, bersifat pelagis, dan bisa berenang sampai jarak yang jauh untuk memperluas distribusi (Anonim 2011).

Kerusakan terumbu karang di Pantai Meras akhir-akhir ini dapat menyebabkan penurunan populasi Echinodermata. Hal ini dikhawatirkan akan mengganggu kelestariannya di Pantai Meras. Informasi mengenai kehadiran Fauna Echinodermata di Pantai Meras, Kecamatan Bunaken, Sulawesi Utara masih kurang. Beberapa informasi yang telah ada yaitu dari perairan Tanjung Merah Selat Lembeh, Sulawesi Utara. Berdasarkan ancaman akan terjadinya penurunan populasi Echinodermta akibat kerusakan terumbu karang tersebut, perlu dilakukan penelitian tentang diversitas Echinodermata di Pantai Meras, Kecamatan Bunaken, Sulawesi Utara.

\section{METODE \\ Waktu dan Tempat}

Penelitian dilaksanakan di

Pantai Meras, Kecamatan Bunaken, Sulawesi Utara pada September 2011. Identifikasi sampel dilakukan di lapangan dan di Laboratorium Biokonservasi, Jurusan Biologi, Fakultas Matematika dan IImu Pengetahuan Alam, Universitas Sam Ratulangi, Manado.

\section{Alat dan Bahan}

Alat dan bahan yang digunakan yaitu tali plastik, patok kayu, meteran, kertas lakmus, stopwatch, kamera digital, termometer, buku catatan, dan kuadrat berukuran $1 \times 1$ meter.

\section{Teknik Pengambilan Sampel}

Pengambilan sampel dilakukan dengan menggunakan kombinasi metode transek garis dan metoda kuadrat. Pengambilan sampel pada masing-masing lokasi dilakukan pada saat surut terendah dengan menarik 3 garis transek dengan panjang transek masing-masing 100 meter ke arah laut. Petak kuadarat yang berbentuk 1 x 1 meter selanjutnya diletakkan dengan berjarak 10 meter pada masing-masing kuadrat. Parameter lingkungan yang diukur dan diamati yaitu $\mathrm{pH}$, kecerahan dan suhu air laut serta jenis substrat. Sampel yang diketahui langsung diidentifikasi di lapangan dan yang belum teridentifikasi diambil dan dibawa untuk diidentifikasi di laboratorium. Identifikasi dilakukan dengan menggunakan buku identifikasi dari Susetiono (2004).

\section{Analisis Data}

Data yang didapatkan di lapangan dianalisis untuk mendapatkan nilai Kepadatan, Frekuensi, Indeks Nilai Penting, dan Indeks Diversitas Shannon dan Wienner $\left(H^{\prime}\right)$.

\section{HASIL DAN PEMBAHASAN}

Echinodermata yang ditemukan sebanyak 8 species yang merupakan anggota dari 3 kelas. Spesies-spesies dari Kelas Asteroidea ada 3 species yaitu Protoreaster nodusus, Archaster typicus, dan Linckia leavigata. Species dari Kelas Echinoidea ada 4 species yaitu Diadema setosum, Echinometra mathei, Astropyga 
radiata, dan Tripneustes gratilla. Species dari Kelas Holothuroidea hanya ada satu species yaitu Holothuria atra. Species dari Kelas Crinoidea tidak ditemukan karena tempat hidup Crinoidea tersebut biasanya di daerah tubir untuk mempertahankan tubuhnya dari hantaman gelombang sehingga sulit untuk ditemukan (Yusron 2006).

Species dari Kelas Ophiuroidea juga tidak ditemukan karena biasanya hewan ini sangat aktif di malam hari dan dapat dikatakan sebagai hewan nokturnal (Anonim 2010), sedangkan penelitian dilakukan pada siang hari. Selain itu, cara hidup Ophiuroidea yang sering menempati tempat-tempat yang cenderung keras seperti bebatuan atau karang dan ada juga yang hidup di celah-celah bebatuan untuk mempertahankan diri dari hantaman gelombang ataupun predator. Spesies yang mendominasi dari kelas Echinoidea yaitu D.setosum yang berjumlah sebanyak 338 individu dan paling sedikit yaitu H.atra dan $A$. radiate yang hanya ditemukan 1 individu. (Tabel 1). Hasil ini diambil dari 1 lokasi yang sama tapi memiliki habitat yang berbeda, yaitu berpasir, padang lamun, dan berkarang.

Echinodermata sangat menyukai padang lamun yang merupakan sumber makanan bagi fauna ini sehingga banyak ditemukan di daerah lamun, terutama dari Kelas Aasteroidea. Dari 3 spesies yang ditemukan, hanya A.typicus yang tidak ada di daerah lamun (Tabel 1) karena habitat dari spesies ini hanya di temukan di pasir.

Menurut Nontji (1993), species dari Kelas Asteroidea hidup pada daerah yang memiliki terumbu karang, pasir dan padang lamun.

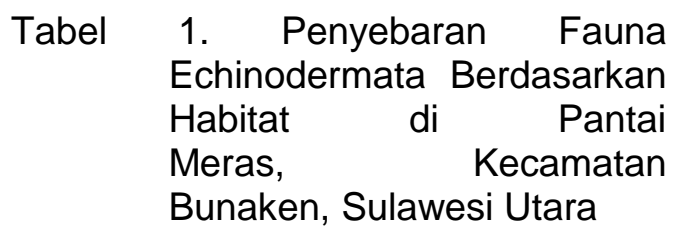

\begin{tabular}{clccc}
\hline No & Kelas/Spesies & Pasir & Lamun & Karang \\
\hline I & Asteroidea & & & \\
1 & Protoreaster nodusus & + & + & + \\
2 & Archaster typicus & + & - & - \\
3 & Linckia leavigata & + & + & - \\
II & Echinoidea & & & \\
4 & Diadema setosum & + & + & + \\
5 & Echinometra mathei & - & + & + \\
6 & Astropyga radiate & - & + & - \\
7 & Tripneustes gratilla & - & + & + \\
III & Holothuroidea & & & - \\
8 & Holothuria atra & - & + & \\
& & & & \\
\hline
\end{tabular}

Keterangan $:(+)=$ ada $(-)=$ tidak ada

Jumlah individu tertinggi dari ketiga transek yaitu pada Transek III. Hal ini disebabkan karena pada Transek III terdapat dua spesies Echinodermata yang hidupnya berkoloni yang memiliki jumlah individu relatif banyak yaitu A.typicus dan D.setosum (Tabel 2). Menurut Nontji (1993), spesies D.setosum hidup secara berkelompok dan berkisar antara 20-40 individu ataupun lebih. Sedangkan pada individu dari species yang lain banyak ditemukan hidup soliter atau hidup sendiri.

Selain itu pada Transek III lokasinya cenderung jarang ditemukan aktivitas manusia dibandingkan dengan pada Transek II yang merupakan sebagai akses warga untuk beraktivitas dari pemukiman warga ke laut sebagai jalan keluar masuk dari perahu-perahu nelayan meskipun pada Transek II didapatkan 6 spesies dari 3 kelas Echinodermata. Jumlah species pada Transek I cenderung hampir seperti pada Transek III yang jarang ditemukan aktivitas manusia. Berdasarkan hasil tersebut, jumlah species Echinodermata tidak banyak dijumpai karena sulit ditemukan. 
Echinodermata memiliki sifat hidup cenderung bersembunyi di bebatuan atau membenamkan diri dalam pasir untuk menghindari hantaman gelombang bahkan untuk melindungi diri dari predator (BTNB 2010).

Tabel 2. Daftar Jenis Spesies Echinodermata dari 3 Transek di Pantai Meras, Kecamatan Bunaken, Sulawesi Utara

\begin{tabular}{lllll}
\hline \multirow{2}{*}{ No } & Nama spesies & \multicolumn{3}{c}{ Transek } \\
\cline { 3 - 5 } & & \multicolumn{1}{c}{ I } & II & III \\
\hline 1 & Protoreaster nodusus & 1 & 35 & 32 \\
2 & Archaster typicus & 0 & 25 & 35 \\
3 & Linckia leavigata & 16 & 1 & 0 \\
4 & Diadema setosum & 169 & 33 & 132 \\
5 & Echinometra mathei & 8 & 0 & 0 \\
6 & Astropyga radiate & 0 & 1 & 0 \\
7 & Tripneustes gratilia & 0 & 6 & 5 \\
8 & Holothuria atra & 0 & 0 & 1 \\
\hline & Jumlah Spesies & 4 & 6 & 5 \\
\hline & Jumlah Individu & 194 & 101 & 205 \\
\hline & Indeks Diversitas (H') & 0.48 & 1.31 & 0.96 \\
\hline
\end{tabular}

Dari hasil yang ada pada Tabel 3 dapat dilihat bahwa nilai (K), (KR), $(F)$, (FR), dan INP tertinggi terdapat pada D.setosum berturut-turut yaitu (11.13), (67.04), (0.8), (33.75), dan (100.79), sedangkan yang memiliki nilai yang terendah ada dua spesies yaitu A.radiata dan $H$.atra yaitu (0.03),
(0.18), (0.03), (1.26), dan (1.44). Hal ini disebabkan karena pada lokasi penelitian terdapat karang yang banyak baik hidup maupun mati meskipun ada juga padang lamun. Menurut Romimohtarto dan Juwana (2001), D.setosum hidup pada karang hidup maupun mati, bebatuan, dan pasir. Hal ini disebabkan, pada Transek 2 terdapat padang lamun yang lebih luas dibandingkan dengan Transek 1 dan Transek 3. Menurut Clark dan Rowe (1971), anggota dari Filum Echinodermata mempunyai peranan penting dalam jaring-jaring makanan pada ekosistem lamun dan sebagai hewan herbivora, karnivora, omnivora ataupun sebagai pemakan detritus.

Yusron dan Susetiono (2005) melaporkan komposisi species dariEchinodermata di Perairan Tanjung Merah, Selat Lembeh Sulawesi Utara. Mereka menemukan 25 spesies Echinodermata yang termasuk dalam 4 kelas yaitu Kelas Holothuroidea (teripang) diwakili 7 species, Kelas Echinoidea (bulu babi) diwakili oleh 5 species, Kelas Asteroidea (bintang laut) diwakili oleh 7 species, dan Kelas Ophiuroidea (bintang mengular) diwakili 7 species, serta nilai $H^{\prime}$ masih berada dalam

Tabel 3. Nilai Kepadatan (K), Kepadatan Relatif (KR), Frekuensi (F), Frekuensi Relatif (FR), dan Indeks Nilai Penting (INP)

\begin{tabular}{clccccc}
\hline No & Nama spesies & $\mathrm{K}$ & $\mathrm{Kr}(\%)$ & $\mathrm{F}$ & $\mathrm{Fr}(\%)$ & $\mathrm{INP}$ \\
\hline 1 & Protoreaster nodusus & 2.26 & 13.61 & 0.63 & 26.58 & 40.19 \\
2 & Archaster typicus & 2 & 12.04 & 0.26 & 10.97 & 23.01 \\
3 & Linckia leavigata & 0.56 & 3.37 & 0.26 & 10.97 & 14.34 \\
4 & Diadema setosum & 11.13 & 67.04 & 0.8 & 33.75 & 100.79 \\
5 & Echinometra mathei & 0.26 & 1.56 & 0.1 & 4.21 & 5.77 \\
6 & Astropyga radiata & 0.03 & 0.18 & 0.03 & 1.26 & 1.44 \\
7 & Tripneustes gratilla & 0.36 & 2.16 & 0.26 & 10.97 & 13.13 \\
8 & Holothuria atra & 0.03 & 0.18 & 0.03 & 1.26 & 1.44 \\
\hline
\end{tabular}


kondisi diversitas sedang yaitu $1-3$. Bila dibandingkan dengan hasil penelitian tersebut maka kekayaan species dari Echinodermata di Pantai Meras, Kecamatan Bunaken, Sulawesi Utara relatif lebih rendah.

\section{KESIMPULAN}

Filum Echinodermata di Pantai
Meras, Kecamatan Bunaken, Sulawesi Utara memilih habitat yang berpasir, padang lamun dan karang hidup maupun karang mati. Pada ketiga transek ditemukan 8 spesies Echinodermata yang termasuk dalam 3 kelas yaitu Kelas Asteroidea (bintang laut) sebanyak 3 spesies (Linckia leavigata, Protoreaster nodusus, Archaster typicus), Kelas Echinoidea sebanyak 4 spesies (Diadema setosum, Echinometra mathei, Astropyga radiata, Tripneustes gratilla), dan Kelas Holothuroidea sebanyak 1 spesies (Holothuria atra). Spesies dari Kelas Crinoidea dan Kelas Ophiuroidea tidak ditemukan karena habitat di Pantai Meras tidak sesuai dengan habitat untuk 2 kelas ini yang hidup di daerah tubir laut dan di dalam bebatuan yang keras.

Nilai indeks diversitas $\left(\mathrm{H}^{\prime}\right)$ dari Echinodermata di Meras berkisar antara 0.48-1.31. Nilai ini menunjukkan bahwa diversitas dari Echinodermata di Meras Kecamatan Bunaken, Selawesi Utara memiliki diversitas dcari rendah hingga sedang.

\section{DAFTAR PUSTAKA}

Anonim (2010) Hewan Berkulit Duri (Bintang Laut). http://biologinews.blogspot.com/2010/12/hewan -berkulit-duri-bintang-laut.html.

Diakses pada Oktober 2011

Anonim (2011)

Animalia

Echinodermata.

http://zipcodezoo.com/Key/Animalia /Echinodermata. [September. 2011]

[BTNB] Balai Taman Nasional Baluran (2010) Pengamatan Invertebrata (Echinodermata) di Pantai Bama, SPTNW I Bengkol. Balai Taman Nasional Baluran, Baluran. http://balurannationalpark.web.id/w p-content/uploads/2011/04/2010-

PengamatanlnvertebratadiBama.pd f. Diakses pada September 2011

Clark AM, Rowe FEW (1971) Monograph of Shallow-Water Indo West Pacific Echinoderms.Trustees of the British Museum (Natural History), London, p.238

Nontji A (1993) Laut Nusantara. Djambatan, Jakarta

Susetiono (2004) Fauna Padang Lamun Tanjung Merah Selat Lembeh. Pusat Penelitian Oseanografi-LIPI, Jakarta

Yusron E, Susetiono (2005) Fauna Echinodermata dari Perairan Tanjung Merah Selat LembehSulawesi Utara. Makara Sains, 9 (2): 60-65

Yusron E (2006) Biodiversitas Ekhinodermata di Perairan Pantai Takofi, Pulau Moti Maluku Utara. Makara Sains, Vol. 10 (1): 41-46 
